\title{
STEREO PHOTO SERIES FOR QUANTIFYING BIOMASS FOR THE CERRADO VEGETATION IN CENTRAL BRAZIL
}

\author{
Roger D. Ottmar ${ }^{1}$ \\ Robert E. Vihnanek ${ }^{1}$ \\ Heloisa S. Miranda ${ }^{2}$ \\ Margarete N. Sato ${ }^{2}$ \\ Saulo M. A. Andrade ${ }^{2}$
}

\begin{abstract}
RESUMO
As séries de estereo-fotografias para o Cerrado representam uma variação de formas fisionômicas do Cerrado, incluindo campo limpo, campo sujo, cerrado ralo, cerrado sensu stricto e cerrado denso. As áreas incluem fotografias grande angular e um par de estereo-fotografias complementadas com informações sobre o combustível vivo e morto, a estrutura e composição da vegetação. Estas séries de estereo-fotografias são uma importante ferramenta de manejo, que pode ser usada na avaliação de paisagens através da estimativa do combustível vivo e morto, bem como da estrutura da vegetação. Dados de inventário como os fornecidos nestas séries podem ser usados como variáveis para, por exemplo, a avaliação de "habitats" de animais e insetos, ciclagem de nutrients, microclima e estimativas de seqüestro de carbono. Aqueles que trabalham com pesquisas em fogo encontrarão dados importantes para a predição de consumo de combustível, produção de fumaça e efeitos do fogo durante incêndios florestais e queimadas prescritas.

Palavras-chave: Cerrado, biomassa, combustível, séries de fotografias
\end{abstract}

\section{INTRODUCTION}

The natural fuels photo series is a set of data and photographs that collectively display a range of natural conditions and fuel loadings in a wide variety of ecosystem types throughout the Americas from central Alaska to central Brazil. Fire managers are the primary target audience of the natural fuels photo series, although the data presented will also prove useful for scientists and managers in other natural resource fields.

The first six volumes of the natural fuels photo series are grouped and published by geographical region of the United States. Volume I (Ottmar et al. 1998) included sites in mixed-conifer, western juniper, sagebrush, and grassland ecosystem types in the interior Pacific Northwest. Volume II (Ottmar and Vihnanek 1998) included sites in black spruce and white spruce ecosystem types in Alaska. Volume III (Ottmar et al. 2000a) included sites in lodgepole pine, quaking aspen, and gambel oak ecosystem types in the Rocky Mountains. Volume IV (Ottmar et al. 2000b) included sites in pinyon-juniper, sagebrush, and chaparral ecosystem types in the Southwest. Volume V (Ottmar et al.,
1999) included sites in red and white pine northern tallgrass prairie, and mixed-oak ecosystem types in the Midwest. Volume VI (Ottmar and Vihnanek 2000) included sites in longleaf pine, pocosin, and marshgrass ecosystem types in the Southeast.

Additional published or in press volumes include sites in grassland, shrubland, woodland and forest types in Hawaii (Wright et al. 2002); jack pine in the Lake States (Ottmar et al. 2002); hardwoods with spruce succession in Alaska (Ottmar and Vihnanek 2002); and sand hill, sand pine scrub, hardwoods with white pine, and an extension of the longleaf and marshgrass types in the Southeast (Ottmar et al. 2003). A volume to characterize western deciduous oaks and manzanita/ceanothus types is currently being compiled and fieldwork and analysis is ongoing in pitch pine/scrub, balsam fir/red spruce, and mixed hardwoods (beech/birch/maple) types in the Northeast U.S. Work in fuel types found in the Missouri Breaks in eastern Montana, and in southern Arizona and New Mexico has also been funded and is currently being planned. While the

\footnotetext{
${ }^{1}$ USDA Forest Service

${ }^{2}$ Universidade de Brasília
} 
primary focus has been on ecosystems found throughout the United States, a volume has also been produced for savannah (cerrado) ecosystem types in central Brazil (Ottmar et. al. 2001) and a volume is under development for pine and oak forests in the Sierra de Manantlan and additional types in the Sierra de Arteaga, Mexico.

Generally, sites include wide-angle and stereo-pair photographs supplemented with information on living and dead fuels and vegetation, and where appropriate, stand structure and composition within the area visible in the photographs. The sites in each volume provide a basis for appraising and describing woody material, vegetation, and stand conditions in different ecosystems.

\section{Why Is The Photo Series Needed?}

The natural fuels photo series are land management tools that can be used to assess landscapes through appraisal of living and dead woody material and vegetation (i.e., fuels) and stand characteristics. Once an assessment has been completed, stand treatment options, such as prescribed fire or harvesting, can be planned and implemented to better achieve desired effects while minimizing negative impacts on other resources.

The photo series has application in several branches of natural resource science and management. Inventory data found in each volume can be used as inputs for evaluating animal and insect habitat, nutrient cycling, and microclimate, for example. Fire managers will find the photo series useful for predicting fuel consumption, smoke production, fire behavior, and fire effects during wildfires and prescribed fires. In addition, the photo series can be used to appraise carbon sequestration, an important factor in predictions of future climate, and to link remotely sensed signatures to live and dead fuels on the ground.

Ground inventory procedures that directly measure site conditions (e.g., fuel loading and arrangement, vegetation structure and composition, etc.) exist for most ecosystem types and are useful when a high degree of accuracy is required. Ground inventory is timeconsuming and expensive, however, and photo series can be used to make quick, easy, and inexpensive determinations of fuel quantities and stand conditions when less precise estimates are acceptable.

\section{How Was The Photo Series Developed?}

Sites photographed for the various series are selected to show ranges of important ecosystem characteristics, such as down and dead woody material loading, understory composition, overstory development, etc.

\section{Photographs And Information Arrangement}

Stereo-pair photographs are included in each photo series volume. The threedimensional image obtained by viewing the photographs with a stereoscope improves the ability of the land manager to appraise natural fuel, vegetation, and stand structure conditions. Larger, wide-angle photographs are included for additional comparisons.

The photographs and accompanying data summaries are presented as single sites organized into series. Each site is arranged to occupy two facing pages. In most cases the upper page contains the wide-angle $(50 \mathrm{~mm})$ photograph, and general site and stand information. The lower page typically includes the stereo-pair photographs and summaries of overstory structure and composition, understory vegetation structure and composition, forest floor composition and loading, and dead and down woody material loading and density by size class.

\section{Using The Photo Series}

To use the photo series one makes a visual inventory of the site by observing fuel and stand conditions within their field of view and comparing them with the stereo-pair photographs. The user observes each characteristic of interest (e.g., 3.1 to 9.0-inch woody material loading) and selects a photo series site (or sites) that nearly matches (or brackets) the observed characteristics. The quantitative value of the characteristic being estimated can then be read from the data summary accompanying the selected photo series site, or a value can be interpolated using the data from more than one site. These steps are repeated for each size class or stand characteristic of interest and the total loading or stand condition can then be calculated by summing the estimates. 


\section{How do i get the photo series?}

Volumes I-VI, IIa, Va, and VIa are available for purchase from the National Interagency Fire Center, Great Basin Cache Supply office, Publication Management System working team in Boise, Idaho (Fax: 208-387-5573

or http://www.fire.blm.gov/bk/pms.htm). The Hawaii volume is available upon request from the Pacific Northwest Research Station, Pacific Wildland Fire Sciences Laboratory (rvihnanek@ffs.fed.us). The Brasil volume can be requested by contacting one of the following: Dr. Heloisa Miranda, University of Brasilia (hmiranda@unb.br) or Robert Vihnanek (rvihnanek@ffs.fed.us).

\section{PHOTO SERIES CITATIONS}

Ottmar, Roger D.; Vihnanek, Robert E.; Wright, Clinton S. 1998. Stereo photo series for quantifying natural fuels. Volume I: mixedconifer with mortality, western juniper, sagebrush, and grassland types in the interior Pacific Northwest. PMS-830. Boise, ID: National Wildfire Coordinating Group, National Interagency Fire Center. 73 p. Order Number - NFES \#2580 \$33.07

Ottmar, Roger D.; Vihnanek, Robert E. 1998. Stereo photo series for quantifying natural fuels. Volume II: black spruce and white spruce types in Alaska. PMS-831. Boise, ID: National Wildfire Coordinating Group, National Interagency Fire Center. 65 p. Order Number - NFES \#2581 \$32.21

Ottmar, Roger D.; Vihnanek, Robert E.; Wright, Clinton S. 2000a. Stereo photo series for quantifying natural fuels. Volume III: lodgepole pine, quaking aspen, and gambel oak types in the Rocky Mountains. PMS-832. Boise, ID: National Wildfire Coordinating Group, National Interagency Fire Center. 85 p. Order Number - NFES \#2629 \$36.82

Ottmar, Roger D.; Vihnanek, Robert E; Regelbrugge, Jon C. 2000b. Stereo photo series for quantifying natural fuels. Volume IV: pinyon-juniper, sagebrush, and chaparral types in the Southwestern United States. PMS 833. Boise, ID: National Wildfire Coordinating Group, National Interagency Fire Center. 97 p. Order Number - NFES \#1084 \$27.53
Ottmar, Roger D.; Vihnanek, Robert E. 1999. Stereo photo series for quantifying natural fuels. Volume V: Midwest red and white pine, northern tallgrass prairie, and mixed oak types in the Central and Lake States. PMS 834. Boise, ID: National Wildfire Coordinating Group, National Interagency Fire Center. 99 p. Order Number - NFES \#2579 \$36.52

Ottmar, Roger D.; Vihnanek, Robert E. 2000. Stereo photo series for quantifying natural fuels. Volume VI: Longleaf pine, pocosin, and marshgrass types in the Southeast United States. PMS 835. Boise, ID: National Wildfire Coordinating Group, National Interagency Fire Center. 56 p. Order Number - NFES \#2630 \$30.09

Ottmar, Roger D.; Vihnanek, Robert E. 2002. Stereo photo series for quantifying natural fuels. Volume IIa: Hardwoods with spruce in Alaska. PMS 836. Boise, ID: National Wildfire Coordinating Group, National Interagency Fire Center. 41 p. Order Number - NFES \#2668 \$33.57

Ottmar, Roger D.; Vihnanek, Robert E.; Wright, Clinton S. 2002. Stereo photo series for quantifying natural fuels. Volume Va: Jack pine in the Lake States. PMS 837. Boise, ID: National Wildfire Coordinating Group, National Interagency Fire Center. 49 p. Order Number - NFES \#2669 \$36.84

Ottmar, Roger D.; Vihnanek, Robert E.; Mathey, Jared W. 2003. Stereo photo series for quantifying natural fuels. Volume VIa: Sand hill, sand pine scrub, and hardwoods with white pine types in the Southeast United States with supplemental sites for volume VI. PMS 838. Boise, ID: National Wildfire Coordinating Group, National Interagency Fire Center. 78 p. Order Number - NFES \#1119 \$(unknown at this time). Available summer 2004.

Ottmar, Roger D.; Vihnanek, Robert E.; Miranda, Heloisa S.; Sato, Margarete N.; Andrade, Saulo M.A. 2001. Stereo photo series for quantifying Cerrado fuels in central Brazil - Volume I. Gen. Tech. Rep. PNW-GTR-519. Portland, OR: U.S. Department of Agriculture, Forest Service, Pacific Northwest Research Station. 87 p. Available from Pacific Wildland Fire Sciences Laboratory. Send requests via email to: bvihnanek@fs.fed.us 
Wright, Clinton S.; Ottmar, Roger D.; Vihnanek, Robert E.; Weise, David R. 2002. Stereo photo series for quantifying natural fuels. Grassland, shrubland, woodland, and forest types in Hawaii. Gen. Tech. Rep. PNW-GTR545. Portland, OR: U.S. Department of Agriculture, Forest Service, Pacific Northwest Research Station. 91 p. Available from Pacific Wildland Fire Sciences Laboratory. Send requests via e-mail to: cwright@fs.fed.us. 